Hegemonia - Revista Eletrônica do Programa de Mestrado em Direitos Humanos, Cidadania e Violência/Ciência Política do Centro Universitário Unieuro

ISSN: $1809-1261$

UNIEURO, Brasília, número 24, Julho a Dezembro de 2018, pp. 288-309.

Recebido em: 6/1/2018

Avaliado em: 27/2/2018

Aprovado em: 20/3/2018

\title{
INSTITUTOS DE MEDIAÇÃO E ARBITRAGEM: FORMAS ALTERNATIVAS DE SOLUÇÕES DE CONFLITOS E ACESSO À JUSTIÇA
}

Cristina Melo Gonçalves, ${ }^{1}$ Ida Geovanna Medeiros da Costa $^{2}$ e Victor Vinícius Alves ${ }^{3}$

Resumo: O presente artigo reflete o tema da mediação e a arbitragem como formas de modalidade alternativa de solução de conflitos, estabelecendo de modo objetivo suas características e alcance. Palavras-chave: Sociedade. Conflito. Solução. Direito. Mediação. Arbitragem

Abstract: This article reflects the theme of mediation and arbitration as forms of alternative modality of conflict resolution, objectively establishing its characteristics and scope.

Keywords: Society. Conflict. Solution. Right. Mediation. Arbitration.

1 - INTRODUÇÃO: Tipos de soluções de conflitos contemplados pelo ordenamento jurídico brasileiro

É de suma importância entender que o ordenamento jurídico brasileiro suporta dois tipos de soluções de conflitos, os quais se intitulam, autocomposição e heterocomposição. Assim, sobre a autocomposição - método primitivo de resolução de conflito - primeiramente, com efeito, explicita, Carlos Eduardo Vanin, autor do texto, “O que é autocomposição?”, em que é mostrado suas três diferentes formas, in verbis:

Autocomposição é um método primitivo de resolução de conflitos entre pessoas e consiste em: um dos indivíduos, ou ambos, abrem

\footnotetext{
${ }^{1}$ Doutoranda em Parcerias na Saúde na Universidade de Brasília. Docente do Centro Universitário Unieuro.

2 Discente do Curso de Graduação da Faculdade de Direito do Centro Universitário Euro-Americano (UNIEURO/DF).

3 Discente do Curso de Graduação da Faculdade de Direito do Centro Universitário Euro-Americano (UNIEURO/DF)
} 
Hegemonia - Revista Eletrônica do Programa de Mestrado em Direitos Humanos, Cidadania e Violência/Ciência Política do Centro Universitário Unieuro

ISSN: $1809-1261$

UNIEURO, Brasília, número 24, Julho a Dezembro de 2018, pp. 288-309.

mão do seu interesse por inteiro ou de parte dele. Portanto pode se afirmar que é um ajuste de vontades entre as partes (pressupondo pacificada e liberdade), onde pelo menos uma delas abre mão de seus interesses ou de parte deles. Podendo haver a participação de terceiros (árbitro ou mediador). A autocomposição pode ocorrer de três formas (as quais, de certa maneira, sobrevivem até hoje com referência aos interesses disponíveis): DESISTÊNCIA - consiste em dar início à proteção do Direito lesado ou ameaçado de lesão, e desiste de protegê-lo (renúncia à pretensão). SUBMISSÃO consiste na aceitação de resolução de conflito oferecido pela parte contrária (renúncia à resistência oferecida à pretensão). TRANSAÇÃO - consiste na troca equilibrada e recíprocas entre as partes (concessões recíprocas). 15

Ainda sobre os tipos de soluções de conflitos, sobre a heterocomposição, o mesmo, também, aponta, in verbis:

A heterocomposição é a técnica pela qual as partes elegem um terceiro para "julgar" a lide com as mesmas prerrogativas do poder judiciário. As duas formas principais são: Arbitragem (Lei 9307/96) e Jurisdição. [16]

Aliás, é imperioso destacar que, apesar do objeto de estudo deste artigo ser a mediação e a arbitragem, é, também, igualmente importante, refletir sobre a importância da jurisdição. Assim, ela é una e indivisível, e como o Estado é o detentor soberano da capacidade de julgar litígios que surgirem no seio da sociedade, tudo o que não for julgado, solucionado pelo próprio Estado, é considerado equivalente jurisdicional, num aspecto residual.

No entanto, uma questão deve ser levantada: o que viria a ser um “equivalente jurisdicional”? A respeito disso, o renomado doutrinador brasileiro, Freddie Didier Jr., conceitua, in verbis:

Equivalentes jurisdicionais são as formas não-jurisdicionais de solução de conflitos. São chamados de equivalentes exatamente porque, não sendo jurisdição, funcionam como técnica de tutela dos 
Hegemonia - Revista Eletrônica do Programa de Mestrado em Direitos Humanos, Cidadania e Violência/Ciência Política do Centro Universitário Unieuro

ISSN: $1809-1261$

UNIEURO, Brasília, número 24, Julho a Dezembro de 2018, pp. 288-309.

direitos, resolvendo conflitos ou certificando situações jurídicas." [1]

No mesmo raciocínio, Elpídio Donizetti, complementa, in verbis:

Ao contrário da jurisdição, as formas alternativas não são dotadas de definitividade, submetendo--se ao controle do Judiciário. No entanto, os equivalentes jurisdicionais apresentam o benefício da celeridade - porquanto menos formalistas do que um processo comum - e do baixo custo financeiro, que é elevado nos processos jurisdicionais (taxas judiciárias, honorários advocatícios, custas de perícia...) e que muitas vezes sequer existem nos meios alternativos. Tais particularidades, aliadas à percepção de que o Estado, muitas vezes, falha em sua missão pacificadora, têm contribuído para uma valorização crescente dos meios não jurisdicionais de pacificação social. [2]

Vale atentar que a arbitragem é um equivalente jurisdicional ainda muito polêmico quanto à sua natureza, pois alguns juristas - tais como, Freddie Didier Jr. e Marinoni, -, por exemplo, a entendem não como um equivalente e, sim, como um "exercício de jurisdição por autoridade nãoestatal". Ou seja, a jurisdição privada. E apesar de esse ser um entendimento minoritário, não deve ser ignorado, mas, levado em conta como motivação para realização de estudos mais profundos.

De toda forma, a autocomposição sendo inquestionavelmente uma técnica de pacificação de conflitos é, assim, conceituada por Freddie Diddier Jr., in verbis:

É a forma de solução de conflito pelo consentimento espontâneo de um dos contentores em sacrificar o interesse próprio, no todo ou em parte, em favor do interesse alheio. É a solução altruísta do litígio. Considerada, atualmente, como legítimo meio alternativo de pacificação social. Avança-se no sentido de acabar com o dogma da exclusividade estatal para a solução dos 
Hegemonia - Revista Eletrônica do Programa de Mestrado em Direitos Humanos, Cidadania e Violência/Ciência Política do Centro Universitário Unieuro

ISSN: $1809-1261$

UNIEURO, Brasília, número 24, Julho a Dezembro de 2018, pp. 288-309.

conflitos de interesses. Pode ocorrer fora ou dentro do processo jurisdicional. [3]

Aliás, com relação a tutela jurisdicional, em outras palavras, mas no mesmo sentido, conceitua, Dinamarco, in verbis:

A tutela jurisdicional não constitui o único meio de eliminação dos conflitos. $\mathrm{Na}$ verdade, a jurisdição é a ultima ratio, a última trincheira na tentativa de pacificação social; fora daquelas hipóteses em que, pela natureza da relação material ou por exigência legal, se fizer necessário o provimento jurisdicional, a jurisdição só atuará quando estritamente necessário. [4]

Assim, levando-se em consideração o que já foi demonstrado, o novo CPC (Lei 13.105/15) integra os meios alternativos em seu artigo $33^{\circ}$, in verbis:

Art. $3^{\circ}$. Não se excluirá da apreciação jurisdicional ameaça ou lesão a direito. $\int 1 .^{\circ}$ É permitida a arbitragem, na forma da lei. $\int 2{ }^{\circ}$ O Estado promoverá, sempre que possível, a solução consensual dos conflitos.

$\int 3 .^{\circ}$ A conciliação, a mediação e outros métodos de solução consensual de conflitos deverão ser estimulados por juízes, advogados, defensores públicos e membros do Ministério Público, inclusive no curso do processo judicial. [5]

Além disso, o poder legislativo tem reiteradamente incentivado a autocomposição, com a edição de diversas leis (Lei 9.307/96 e vide Lei 13.129/15). Aliás, o CPC ratifica e reforça essa tendência ao dedicar um capítulo inteiro para regular a mediação e conciliação - arts. 165 a 175 -, estruturar o procedimento de modo a pôr a tentativa de autocomposição como ato anterior ao oferecimento da defesa pelo réu - arts. 334 e 695 -, permitir a homologação judicial de acordo extrajudicial de qualquer natureza - art. 515, III; art. 725, VIII -, permitir que, no acordo judicial, seja incluída matéria estranha ao objeto litigioso do processo - art. 515, parágrafo $2 .^{\circ}$ - e, por fim, 
Hegemonia - Revista Eletrônica do Programa de Mestrado em Direitos Humanos, Cidadania e Violência/Ciência Política do Centro Universitário Unieuro

ISSN: $1809-1261$

UNIEURO, Brasília, número 24, Julho a Dezembro de 2018, pp. 288-309.

permitir acordos processualistas atípicos. Sendo explícito, assim que o Novo CPC (Lei 13.105/15) sobrepõe e valoriza o princípio do autorregramento das vontades. Portanto, o juiz deve buscar sempre que possível a solução pacífica de conflitos, e em última ratio através de meios coercitivos.

Ademais, a Emenda Constitucional n. 45/2004, consagrou a arbitragem em nível constitucional, no âmbito trabalhista, como está presente nos parágrafos $1^{\circ}$ e $2^{\circ}$, da Constituição Federal de 1988, in verbis:

Art. $1^{\circ}$ A República Federativa do Brasil, formada pela união indissolúvel dos Estados e Municípios e do Distrito Federal, constitui-se em Estado Democrático de Direito e tem fundamentos:

Art.2

2 - Significado e conceito da palavra mediação

Assim como ocorre com todas as palavras, é sabido que existem inúmeros significados para a palavra "mediação", sobretudo, pelo fato de que as palavras, ao longo do tempo, acabam originando-se umas das outras - seja perdendo algumas letras, ou ganhando outras - uma vez que os próprios idiomas também se originam uns dos outros. Fazendo jus, portanto, a este pensamento, segundo o Dicionário da Lingua Portuguesa: Novo Aurélio - século XXI, dentre os vários significados desta palavra, desde o ato de mediar, passando pela ideia de se adquirir conhecimento e sabedoria, de forma ainda mais completa, é possível ser destacado, in verbis:

Ato ou efeito de mediar; Intervenção, intercessão, intermédio; Relação que se estabelece entre duas coisas, ou pessoas, ou conceito, etc; No gnosticismo, função exercida por diferentes potências celestiais na condução do homem à gnose; Intervenção com que se busca produzir um acordo; Processo de acerto de conflitos internacionais, no qual (ao contrário do que se dá na arbitragem) a solução é sugerida e não imposta às partes interessadas; Agenciamento, corretagem. Operação de somar termo a termo duas frações ordinárias; Segundo a doutrina da Igreja Católica, função de Maria e dos Santos junto a Cristo e a Deus. 
Hegemonia - Revista Eletrônica do Programa de Mestrado em Direitos Humanos, Cidadania e Violência/Ciência Política do Centro Universitário Unieuro

ISSN: $1809-1261$

UNIEURO, Brasília, número 24, Julho a Dezembro de 2018, pp. 288-309.

No entanto, como a função deste trabalho é refletir sobre a importância de se criar um projeto de lei no que tange à mediação e à arbitragem, no âmbito do Distrito Federal, o significado jurídico de ambas as palavras, ou o mais próximo de tal concepção, é o que mais interessa e, portanto, também, deve ser apresentado. Dessa forma, o dicionário jurídico, Vocabulário Jurídico, prioriza o seguinte significado, in verbis:

Do latim mediatio (intervenção, intercessão), é o vocábulo empregado, na terminologia jurídica, para indicar todo ato de intervenção de uma pessoa em negócio ou contrato que se realiza entre outras.

Além disso, explica Áureo Simões Júnior, professor e titular da Associação Brasileira de Árbitros e Mediadores, caracterizando a mediação como uma “técnica amigável” que vai

na contramão do que ocorria no passado ou continua a ocorrer na atualidade, por vezes caracterizada pela violência, agressão e falta de consciência. A mediação é, por assim dizer, um "exercício de cidadania", como está escrito, in verbis:

A mediação é uma técnica pela qual, duas ou mais pessoas, em conflito potencial ou real, recorrem a um profissional imparcial, para obterem num espaço curto de tempo e a baixos custos uma solução consensual e amigável, culminando num acordo em que todos ganhem. A mediação é uma resposta ao incremento da agressividade e desumanização de nossos dias, através de uma nova cultura, em que a solução dos conflitos passa por um facilitador profissional que tenta através de várias técnicas, pela conscientização e pelo diálogo proporcionar uma compreensão do problema e dos reais interesses e assim ajudar as partes a acordarem entre si, sem imposição de uma decisão por terceiro, num efetivo exercício de cidadania.

Ainda sobre tal conceito, para Christopher W. Moore, mediador americano e um dos primeiros a introduzir, nos anos 90, a mediação na Polônia, também tendo sido o responsável por 
Hegemonia - Revista Eletrônica do Programa de Mestrado em Direitos Humanos, Cidadania e Violência/Ciência Política do Centro Universitário Unieuro

ISSN: $1809-1261$

UNIEURO, Brasília, número 24, Julho a Dezembro de 2018, pp. 288-309.

cooperar com as estruturas governamentais e não-governamentais dos Estados Unidos, nesse sentido, a mediação é como uma interferência em um conflito que auxilia as partes a chegarem em um acordo comum, como está destacado, in verbis:

A mediação é definida como a interferência em uma negociação ou em um conflito, de uma terceira pessoa aceitável, tendo o poder de decisão limitado ou não autoritário, e que ajuda as partes envolvidas a chegarem, voluntariamente, a um acordo, mutuamente, aceitável em relação às questões em disputa.

Por fim, em síntese, tenho em vista todas as definições anteriores, para o psicólogo e mediador, Juan Carlos Vezzulla, é possível concluir que a mediação detém uma grande eficiência no que tange às resoluções de conflitos, afinal, de forma simples, por meio das próprias partes e com auxílio de um mediador que aponta um caminho, direcionamento para elas, é possível chegar a um acordo, a uma solução, daí sua importância, in verbis:

[...] mediação é a técnica privada de solução de conflitos que vem demonstrando, no mundo, sua grande eficiência nos conflitos interpessoais, pois com ela, são as próprias partes que acham as soluções. O mediador somente as ajuda a procurá-las, introduzindo, com suas técnicas, os critérios e os raciocínios que lhes permitirão um entendimento melhor.

3 - Significado e conceito da palavra arbitragem

Já com relação a palavra arbitragem, segundo, também, o Dicionário da Lingua Portuguesa: Novo Aurélio - século XXI, dentre os vários significados, desde simplesmente o ato de "arbitrar", até chegar na operação de compra, ela consiste, in verbis:

No ato ou efeito de arbitrar; arbitração, arbitramento; O julgamento, decisão ou veredicto de árbitro(s); arbítrio; Operação que consiste na compra (de mercadoria, moeda, título, etc.) onde o preço é mais baixo, e venda subsequente onde o preço é mais alto. 
Hegemonia - Revista Eletrônica do Programa de Mestrado em Direitos Humanos, Cidadania e Violência/Ciência Política do Centro Universitário Unieuro

ISSN: 1809-1261

UNIEURO, Brasília, número 24, Julho a Dezembro de 2018, pp. 288-309.

Tendo em vista tais significados, principalmente, o sob à ótica da ciência jurídica, o dicionário Vocabulário Jurídico, contempla que esta palavra deriva do latim e significa "juiz", bem como a sua função que é, justamente, “arbitrar”, “julgar”. Aliás, este significado é um dos principais enfoques deste trabalho, in verbis:

Derivado do latim arbier (juiz, louvado, jurado), embora por vezes tenha a mesma significação de arbitramento, é, na linguagem jurídica, especialmente empregado para significar o processo que se utiliza, a fim de se dar solução a litígio ou divergência, havida entre duas ou mais pessoas.

No entanto, embora tal palavra signifique “juiz”, bem como sua função, José Cretella Júnior, importante jurista, professor e advogado brasileiro, especializado em direito administrativo, nos traz uma importante reflexão sobre este instituto, afinal, embora seja reconhecido pelo direito comum, trata-se de uma forma de julgamento diferenciada, em que o árbitro assume poderes de juiz, in verbis:

Sistema especial de julgamento, com procedimento, técnica e princípios informativos especiais e com força executória reconhecida pelo direito comum, mas a este subtraído, mediante o qual duas ou mais pessoas físicas ou jurídicas, de direito privado ou de direito público, em conflito de interesses, escolhem de comum acordo, contratualmente, uma terceira pessoa, o árbitro, a quem confiam o papel de resolver-lhes as pendências, anuindo os litigantes em aceitar a decisão proferida [...]

É essencial apontar, também, a definição do jurista Fredie Didier Jr., a respeito da arbitragem e, inclusive, sua reflexão sobre a constitucionalidade, bem como a pacificidade de tal instituto, uma vez que o mesmo é uma opção de salvaguarda dos direitos disponíveis, in verbis:

É técnica de solução de conflitos mediante a qual os conflitantes buscam em uma terceira pessoa, de sua confiança, a solução amigável e "imparcial” (porque não feita pelas partes diretamente) 
Hegemonia - Revista Eletrônica do Programa de Mestrado em Direitos Humanos, Cidadania e Violência/Ciência Política do Centro Universitário Unieuro

ISSN: $1809-1261$

UNIEURO, Brasília, número 24, Julho a Dezembro de 2018, pp. 288-309.

do litígio. É, portanto, heterocomposição.[6][...] Não há qualquer vício de inconstitucionalidade na instituição da arbitragem, que não é compulsória; trata-se de opção conferida a pessoas capazes para solucionar problemas relacionados à direitos disponíveis. Não se admite arbitragem em causas penais. [8]

4 - A diferença entre os dois institutos

Resumidamente, no que diz respeito à diferença entre os institutos da arbitragem e da mediação, é de extrema importância, destacar o conceito apontado pela memorável e conceituada doutrinadora brasileira e ex-professora da Universidade de São Paulo (USP), Ada Pellegrini Grinover - ou seja, enquanto na primeira, são indicados os terceiros, os árbitros que julgam as causas; na segunda, as partes, juntas, decidem por meio de um acordo que, para existir, precisa ser mediado por terceiros que são, justamente, os mediadores. Além disso, ainda sobre a mediação, a doutrinadora reflete sobre aqueles que poderão ser esses "terceiros", in verbis:

$\mathrm{Na}$ arbitragem, a causa é julgada por árbitros indicados pelas partes, como juízes leigos, havendo, portanto, um vencedor e um perdedor. $\mathrm{Na}$ justiça conciliativa, contudo, são as próprias partes que conversam e chegam, juntas, ao consenso: que pode ser atingido diretamente, ou por seus advogados, ou com a ajuda de um terceiro facilitador, que propõe o diálogo.

5 - A história da mediação no contexto alienígena

A mediação surgiu com o propósito de resolução de conflitos existentes entre as civilizações humanas. Consequentemente, a função do mediador passou por um longo e profundo processo histórico. Aliás, de forma mais precisa, tal profissão, por vezes é datada como proveniente dos Estados Unidos, nos anos 70. No entanto, antes mesmo de Cristo, é possível dizer que ela já existia. Basta ter como fonte histórica, o documento mais antigo do mundo - a Bíblia.

Nela, é possível perceber os inúmeros litígios bíblicos existentes na Grécia, Roma e comunidades judaicas e, de forma especial, inúmeras referências à importância do mediador, como está explícito em um dos versículos de Isaías, capítulo 42, in verbis: 
Hegemonia - Revista Eletrônica do Programa de Mestrado em Direitos Humanos, Cidadania e Violência/Ciência Política do Centro Universitário Unieuro

ISSN: $1809-1261$

UNIEURO, Brasília, número 24, Julho a Dezembro de 2018, pp. 288-309.

42:6 Eu, o Senhor, o chamei para a justiça; segurarei firme a sua mão. Eu o guardarei e farei de você um mediador para o povo e uma luz para os gentios $[\ldots]$

Além da importância de tal ofício, é possível perceber a associação da função de mediar ligada ao próprio Jesus Cristo, como está expresso em Gálatas, in verbis:

3:19 Qual era então o propósito da Lei? Foi acrescentada por causa das transgressões, até que viesse o Descendente a quem se referia a promessa, e foi promulgada por meio de anjos, pela mão de um mediador.

Aliás, para a Bíblia, cristãos, pesquisadores, estudiosos etc, Cristo, se não foi o maior mediador da história, ao menos foi, um dos mais importantes, como está presente em algumas passagens de Hebreus, in verbis:

8:6 Agora, porém, o ministério que Jesus recebeu é superior ao deles, assim como também a aliança da qual ele é mediador é superior à antiga, sendo baseada em promessas superiores.

9:15 Por essa razão, Cristo é o mediador de uma nova aliança para os que são chamados recebam a promessa da herança eterna, visto que ele morreu como resgate pelas transgressões cometidas sob a primeira aliança.

Dessa forma, anos depois, a mediação se difunde pela cultura hindu, chinesa, japonesa e islâmica. A China, por exemplo, utiliza a mediação como um instrumento de resolução de conflitos familiares por meio dos Comitês Populares de Conciliação e dos Tribunais de Conciliações.

Com relação à segunda metade do século XX, mais especificamente, no período pós-guerra, os Estados Unidos resolvem criar um modelo alternativo de resolução de conflitos, o intuito era tornar o Poder Judiciário Americano mais célere. Daí é que se origina a famosa Alternative Dispute Resolution - Resolução de Disputa Alternativa - internacionalmente reconhecida como um meio de identificar e solucionar os conflitos. 
Hegemonia - Revista Eletrônica do Programa de Mestrado em Direitos Humanos, Cidadania e Violência/Ciência Política do Centro Universitário Unieuro

ISSN: 1809-1261

UNIEURO, Brasília, número 24, Julho a Dezembro de 2018, pp. 288-309.

Naturalmente, a mediação acabou chegando ao Canadá e em outros países da Europa, não só por sua eficiência, mas, também, pela sua versatilidade, pois pode ser utilizada em conflitos das mais diversas temáticas que vão do meio ambiente, até as causas internacionais.

Por fim, nos anos 80, a mediação se difunde pelo continente asiático, europeu e, também, americano, embora no Brasil, tenha surgido bem antes, ainda no século XIX.

6 - A história da mediação no contexto brasileiro

No Brasil, assim como na maioria dos países, inclusive, os Estados Unidos, a mediação surge para tornar a justiça mais democrática e eficiente. É o que pode ser visto nos artigos 160 e 161 da Constituição Imperial de 1824, in verbis:

Art. 160 - Nas cíveis, e nas penas civilmente intentadas, poderão as Partes nomear juízes

árbitros. Suas Sentenças serão executadas sem recurso, se assim convencionarem as mesmas Partes.

Art. 161 - Sem se fazer constar, que se tem intentado o meio de reconciliação, não se começará Processo algum.

Com a atual Constituição, a Carta Magna promulgada em 1988, é possível ver uma referência a tal instituto, in verbis:

Art. 98. A União, no Distrito Federal e nos Territórios, e os Estados criarão: (EC no 22/99 e EC no 45/2004)

I - juizados especiais, providos por juízes togados, ou togados e leigos, competentes para a conciliação, o julgamento e a execução de causas cíveis de menor complexidade [...]

II - justiça de paz, remunerada, composta de cidadãos eleitos pelo voto direto, universal e secreto, com mandato de quatro anos e competência para, na formação da lei, celebrar casamentos, verificar, de ofício ou em fase de impugnação apresentada, o processo de habilitação e exercer atribuições conciliatórias, sem caráter jurisdicional, além de outras prevista na legislação. 
Hegemonia - Revista Eletrônica do Programa de Mestrado em Direitos Humanos, Cidadania e Violência/Ciência Política do Centro Universitário Unieuro

ISSN: 1809-1261

UNIEURO, Brasília, número 24, Julho a Dezembro de 2018, pp. 288-309.

Por fim, é preciso fazer referência ao fato de que o Ministério do Trabalho foi um dos primeiros a buscar formas extra-jurídicas para resolver conflitos, no que tange às causas não atendidas pela justiça trabalhista. Assim, cria-se a Lei no 10.101, de 19 de dezembro de 2000 que prevê em um dos seus artigos, in verbis:

Art. $4^{\circ}$. Caso a negociação visando à participação nos lucros ou resultados da empresa resulte em impasse, as partes poderão utilizar-se dos seguintes mecanismos de solução de litígio: I - mediação;

II - arbitragem de ofertas finais, utilizando-se, no que couber, os termos da Lei no 9.307, de 23 de setembro de 1996. (Redação dada pela Lei no 12.382 , de 2013).

7 - A história da arbitragem no contexto alienígena

A arbitragem, de forma bastante semelhante à mediação, também surgiu com os povos mais antigos, o que implica dizer que, também, estava associada às crenças, religiões logo, à "vontade dos deuses". Aliás, justamente por isso, como curiosidade histórica, disserta de forma bastante brilhante, o doutrinador Dinamarco, que a função arbitral era atribuída aos sacerdotes ou anciãos, com a confiança que seria utilizada de forma justa, in verbis:

Essa interferência, em geral, era confiada aos sacerdotes, cujas ligações com as divindades garantiam soluções acertadas, de acordo com a vontade dos deuses; ou aos anciãos, que conheciam os costumes do grupo social integrado pelos interessados. [7]

E se é possível dizer que historicamente, surge a função magistral antes mesmo da do legislador - como já observaram Cintra, Grinover e Dinamarco - para o professor, advogado e membro do Conselho Editorial da Revista Brasileira de Arbitragem e da Revista de Arbitragem e Mediação, Pedro A. Batista Martins, a arbitragem surgiu antes mesmo dessas duas figuras estatais, in verbis: 
Hegemonia - Revista Eletrônica do Programa de Mestrado em Direitos Humanos, Cidadania e Violência/Ciência Política do Centro Universitário Unieuro

ISSN: $1809-1261$

UNIEURO, Brasília, número 24, Julho a Dezembro de 2018, pp. 288-309.

Passada a fase primitiva da autotutela, onde imperava a força na solução dos conflitos, a composição dos interesses divergentes passou a ser assegurada ao ancião da tribo.

Indivíduo sábio, com vasta experiência, era ele indicado para atuar como terceiro imparcial, na solução da lide, cabendo às partes acatarem decisão bona fide. $\mathrm{Na}$ ausência de uma legislação positiva, cabia ao ancião-árbitro aplicar à controvérsia, não regras de direito expresso, mas, sim, o costume e os princípios da moral e da ética que predominavam na época.

Daí a afirmativa de a arbitragem ser instituto que precede o legislador e o juiz estatal, pois, sem dúvida, não estava o Estado, nos seus primórdios, devidamente aparelhado para administrar a justiça.

Segundo, ainda, Martins, em 455 a.C., na Grécia Antiga, existiam cláusulas compromissórias no que diz respeito ao tratado entre Espanha e Atenas, uma forma de arbitragem na solução de problemas. Quanto à Roma Antiga, lugar onde a arbitragem se expande, a arbitragem surge com um sistema intitulado lista de nomes de cidadãos idôneos ou iudicium privatum-judez, in verbis:

$\mathrm{Na}$ Roma antiga, a arbitragem ganha relevância e torna-se mais difundida com a expansão do Império Romano. Os romanos criaram o iudicium privatum (lista de nomes de cidadãos

idôneos-judez) que tinha por objeto dirimir, extrajudicialmente, questões resultantes de negócio jurídico entre seus nacionais. $\mathrm{O}$ cumprimento da decisão era garantido pelo Estado que a executava, caso o vencido não a acatasse. Com a invasão do Império Romano pelos bárbaros, a arbitragem também sofre um implemento, já que os habitantes das localidades invadidas, para fugir a aplicação compulsória do direito dos invasores, optavam por dirimir sua contendas via arbitragem, onde as regras legais poderiam ser livremente escolhidas, tornando-se esse instituto meio apropriado 
Hegemonia - Revista Eletrônica do Programa de Mestrado em Direitos Humanos, Cidadania e Violência/Ciência Política do Centro Universitário Unieuro

ISSN: 1809-1261

UNIEURO, Brasília, número 24, Julho a Dezembro de 2018, pp. 288-309.

$$
\begin{aligned}
& \text { para adotar as normas jurídicas aceitas e conhecidas dos } \\
& \text { compromitentes. }
\end{aligned}
$$

Quanto à Idade Média, é possível apontar seu surgimento tendo em vista os conflitos existentes entre nobres, proprietários feudais, comerciantes, enfim, entre as classes econômicas e sociais mais marcantes da época. No século XI, comerciantes a utilizam como forma de fugir das leis da época e da justiça estatal, o que fez com que tempos depois, ela desaparecesse e só retornasse por volta do século XVIII.

No século XIX, após de ter sido bastante utilizada, a arbitragem diminui sua intensidade, mas no final deste mesmo século, volta a ser utilizada, perdurando até os dias de hoje, no século XIX, in verbis:

No século XIX, a prática da arbitragem desacelera-se em razão de sua processualização exagerada, resultante das reformas legais instituídas por Napoleão e que irradiaram-se pelo continente europeu, bem como, pela melhoria dos sistema estatal de administração da justiça.

Contudo, já no final do século XIX, o interesse pela arbitragem é renovado, e sua utilização plenamente revigorada no século $\mathrm{XX}$, com a ratificação de tratados sobre a matéria e a inserção do instituto na grande maioria dos sistemas jurídico nacionais.

8 - A história da arbitragem no contexto brasileiro

Se a mediação, no Brasil, tem início com a Constituição de 1824, a arbitragem têm origens ainda mais remotas, ainda quando pertencia à Portugal. No entanto, segundo Pedro A. Batista Martins, em 1831, quando o país já era independente, é que a arbitragem foi introduzida no Brasil, in verbis:

No campo do direito positivo, podemos novamente constatar a tradição brasileira. A primeira Constituição Política do Império, de 1824, já admitia o uso da arbitragem na solução das disputas entre nacionais e estrangeiros. Ademais, autorizava que a decisão do árbitro restasse irrecorrível, caso as partes estabelecessem a cláusula sem recurso. Posteriormente, a arbitragem foi introduzida no 
Hegemonia - Revista Eletrônica do Programa de Mestrado em Direitos Humanos, Cidadania e Violência/Ciência Política do Centro Universitário Unieuro

ISSN: $1809-1261$

UNIEURO, Brasília, número 24, Julho a Dezembro de 2018, pp. 288-309.

sistema legal de forma obrigatória para a resolução de conflitos originados de contratos de seguro (1831) e de locação de serviços (1837)

Assim, diz o artigo 160 da Constituição de 1824, in verbis:

Art. 160. Nas cíveis e nas penais civilmente intentadas, poderão as partes nomear juízes árbitros.

Suas sentenças serão executadas sem recurso, se assim convencionarem as mesmas partes.

No entanto, anos depois, o legislador da Constituição de 1895, resolveu não contemplar tal instituto para resolução de conflitos interpessoais. Com a Constituição de 1934, a arbitragem é readmitida e, novamente, excluída da Carta Magna de 1937 - embora tenha sido regulada pelo Código de Processo Civil de 1939 - 1946, 1967, só retornando com Constituição de 1988, a começar por seu preâmbulo, in verbis:

PREÂMBULO - Nós, representantes do povo brasileiro, reunidos em Assembleia Nacional Constituinte para instituir um Estado Democrático, destinado a assegurar o exercício dos direitos sociais e individuais, a liberdade, a segurança, o bem-estar, o desenvolvimento, a igualdade e a justiça como valores supremos de uma sociedade fraterna, pluralista e sem preconceitos, fundada na harmonia social e comprometida, na ordem interna e internacional, com a solução pacífica das controvérsias, promulgamos, sob a proteção de Deus, a seguinte CONSTITUIÇÃO DA REPÚBLICA FEDERATIVA DO BRASIL.

Além disso, expressa em alguns de seus artigos, in verbis:

Art. 4. ${ }^{\circ}$ A República Federativa do Brasil rege-se nas duas relações internacionais pelos seguintes princípios:

IX - cooperação entre os povos para o progresso da humanidade; Art. 114 - Compete à Justiça do Trabalho processar e julgar: 
Hegemonia - Revista Eletrônica do Programa de Mestrado em Direitos Humanos, Cidadania e Violência/Ciência Política do Centro Universitário Unieuro

ISSN: $1809-1261$

UNIEURO, Brasília, número 24, Julho a Dezembro de 2018, pp. 288-309.

$\int 6^{\circ}$ Frustrada a negociação coletiva, as partes poderão eleger árbitros.

Por fim, em 1996, a arbitragem passou a ser regulamentada pela Lei $n^{\circ}$ 9.307, de 23 de setembro. Em 2015, foi sancionado o projeto de reforma dessa lei, a Lei no $13.129 / 15$, ampliando o alcance da arbitragem, podendo ser utilizada para solucionar conflitos

relacionados ao Direito do Consumidor, relações trabalhistas e, de forma especial, entre a administração pública direta e indireta, com o intuito de dirimir conflitos patrimoniais.

A arbitragem, no Brasil, é regulamentada pela Lei n 9.307/1996. Pode ser constituída por meio de um negócio jurídico denominado convenção de arbitragem que na forma do art. 3..$^{\circ}$ da lei n.9307/1996, compreende tanto a cláusula compromissória quanto o compromisso arbitral, in verbis:

Cláusula compromissória é a convenção em que as partes decidem, prévia e abstratamente, que as divergências oriundas de certo negócio jurídico serão resolvidas pela arbitragem; as partes, antes do litígio surgir, determinam que, uma vez ele ocorrendo, a sua solução, qualquer que seja o conflito, desde que ocorra de certo negócio jurídico, dar-se-á pela arbitragem. [9] compromisso arbitral é o acordo de vontades para submeter uma controvérsia concreta, já existente, ao juízo arbitral, prescindindo do Poder Judiciário. Trata-se, pois, de um contrato, por meio do qual se renuncia à atividade jurisdicional estatal, relativamente a uma controvérsia específica e não somente especificável. [10]

Para se efetivar a cláusula compromissória, costuma ser necessário que se faça um compromisso arbitral, que regulará o processo arbitral para a solução do conflito que surgiu. No entanto, se a cláusula compromissória for completa (contiver todos os elementos para a instauração imediata da arbitragem), não haverá necessidade de futuro compromisso arbitral.

Eis algumas características da arbitragem no direito brasileiro, in verbis: 
Hegemonia - Revista Eletrônica do Programa de Mestrado em Direitos Humanos, Cidadania e Violência/Ciência Política do Centro Universitário Unieuro

ISSN: $1809-1261$

UNIEURO, Brasília, número 24, Julho a Dezembro de 2018, pp. 288-309.

a) Há possibilidade de escolha da norma de direito material a ser aplicada (art. 2 , parágrafos 1 e 2, lei n. 9307/1996); as partes podem escolher qual a regra a ser aplicável, podendo ainda convencionar que o julgamento de realize com base nos princípios gerais do direito, nos usos e costumes e nas regras internacionais de comércio;

b) Árbitro (art. 13, Lei n. 9307/1996): dois são os requisitos exigidos pela lei para o exercício das funções de árbitro: ser pessoa física e capaz. Os árbitros tem o status de juiz de direito e de fato, sendo equiparados aos servidores públicos para efeitos penais;

c) Desnecessidades de homologação judicial da sentença arbitral ( art. 31, lei n. 9.307/1996), que produz efeitos imediatamente;

d) A sentença arbitral é título executivo judicial (art. 31, lei n. 9307/1996; art. 515,VII, CPC): o arbitro pode decidir, mas não tem o poder para tomar nenhuma providência executiva; e) possibilidade de reconhecimento e execução de sentenças arbitrais produzidas no exterior ( art.34 e segs., lei n. 9307/1996)

e) É discutido, atualmente, a possibilidade de arbitragem nos contratos administrativos, principalmente naqueles relacionados a atividades econômicas submetidas à regulação estatal (telecomunicações, art. 93, XV, da Lei n. 9472/1997; exploração de petróleo e gás natural, art. 43, inciso X, da Lei n. 9478/1997) e às parcerias público-privadas. [11]

A arbitragem poderá ser de direito ou de equidade, a critério das partes. A primeira é aquela em que os árbitros seguem as regras dispostas no ordenamento jurídico para solucionar o litígio. Na segunda, por outro lado, podem os árbitros se afastar das regras de direito para buscar a solução que considerar mais justa. Alexandre Freitas Câmara afirma que a segunda tem vantagens sobre a primeira, especialmente no que se refere à especialização do árbitro. O autor assim exemplifica: 
Hegemonia - Revista Eletrônica do Programa de Mestrado em Direitos Humanos, Cidadania e Violência/Ciência Política do Centro Universitário Unieuro

ISSN: $1809-1261$

UNIEURO, Brasília, número 24, Julho a Dezembro de 2018, pp. 288-309.

[...] Basta pensar, por exemplo, numa arbitragem de equidade envolvendo conflito que diga respeito a uma questão de engenharia, ou química. A se levar tal lide ao Judiciário, o juiz fatalmente convocaria um perito no assunto para assessorá-lo, e dificilmente sua sentença teria orientação diversa, quanto aos fatos, daquela apontada pelo perito em seu laudo. Neste caso, com a arbitragem se poderá entregar a solução da controvérsia diretamente nas mãos do especialista, retirando-se da composição do conflito o juiz, que funcionaria aqui, em verdade, como um mero intermediário entre as pessoas e o expert”. [12]

O jurista Fredie Didier Jr., conceitua também, que há a possibilidade de controle judicial da sentença arbitral, mas apenas em relação à sua validade (arts. 32 e 33, caput, Lei n. 9307/1996). Não se trata de revogar ou modificar a sentença arbitral quanto ao seu mérito, por entendê-la injusta ou por errônea apreciação da prova pelos árbitros, senão de pedir sua anulação por vícios formais. Trata-se de uma espécie de "ação rescisória" da sentença arbitral, que deve ser ajuizada no prazo de noventa dias após o recebimento da intimação da sentença arbitral ou de seu aditamento (art. 33, parágrafo 1, da lei n. 9307/1996). Esta ação rescisória apenas de funda em error in procedendo, não permitindo a rediscussão do quanto foi decidido.

O juiz do processo arbitral é um particular ou uma instituição especializada. Nos termos do art. 13 da Lei de Arbitragem, qualquer pessoa física maior e capaz que não tenha interesse

no litígio poderá exercer as funções de árbitro. No desempenho de suas funçõoes, os árbitros são equiparados a funcionários públicos para fins penais (art. 17) e as decisões por eles proferidas não se sujeitarão a recurso ou homologação pelo Poder Judiciário (art. 18).

A sentença arbitral produz entre as partes e seus sucessores os mesmos efeitos da sentença proferida pelos órgãos do Judiciário e, quando condenatória, constituirá título executivo judicial (art. 31). A decisão arbitral fica imutável pela coisa julgado material.

\section{9 - CONSIDERAÇÕES FINAIS}

A mediação e arbitragem são institutos de extrema importância para o Estado Democrático de Direito. Diante de um cenário em que as demandas judiciais crescem de modo exacerbado, 
Hegemonia - Revista Eletrônica do Programa de Mestrado em Direitos Humanos, Cidadania e Violência/Ciência Política do Centro Universitário Unieuro

ISSN: 1809-1261

UNIEURO, Brasília, número 24, Julho a Dezembro de 2018, pp. 288-309.

onde a sociedade busca o poder judiciário para resolver todos os seus conflitos, desacelerando a funcionalidade do sistema, não dando respostas ao tempo e a hora que se socorre, a Mediação e a Arbitragem é um caminho proposto por nosso ordenamento para acelerar a solução das demandas.

Contudo, se faz necessário que haja uma mudança de paradigma social e estatal de modo a garantir que a sociedade busque com maior frequência esse instituto conciliatório. Em especial, que o Estado, a exemplo, incentive a sociedade inserindo essa modalidade em seus contratos e estruturando a máquina pública para resolver os conflitos obre esse novo prisma.

\section{BIBLIOGRAFIA}

[1] Didier Jr. Fredie. Curso de direito processual civil: introdução ao direito processual civil, parte geral e processo de conhecimento. 17.ed.-Salvador:Jus Podivm, 2015. V.1

[2] Donizetti, Elpidio. Curso didático de direito processual civil. 20.ed.rev.atual. e ampl: São Paulo:Atlas,2017.

[3]Didier Jr.,Fredie. Curso de direito processual civil: introdução ao direito processual civil, parte geral e processo de conhecimento. 17.ed.-Salvador:Jus Podivm, 2015. V.1

[4]DINAMARCO, cândido rangel.Op.Cit. p. 118-119

[5] Planalto. Disponível em:

http://www.planalto.gov.br/ccivil_03/_ato2015-2018/2015/lei/113105.htm

Acessado em 12 de setembro de 2017

[6] Didier Jr.,Fredie. Curso de direito processual civil: introdução ao direito processual civil, parte geral e processo de conhecimento. 17.ed.-Salvador:Jus Podivm, 2015. V.1. p 169

[7] CINTRA. Carlos Araújo; DINAMARCO, Cândido Rangel; GRINOVER, Ada Pellegrini. Teoria geral do processo.17.ed.Sao Paulo: Malheiros, 2001.

[8] Didier Jr.,Fredie. Curso de direito processual civil: introdução ao direito processual civil, parte geral e processo de conhecimento. 17.ed.-Salvador:Jus Podivm, 2015. V.1. p.170 
Artigo original

Hegemonia - Revista Eletrônica do Programa de Mestrado em Direitos Humanos, Cidadania e Violência/Ciência Política do Centro Universitário Unieuro

ISSN: 1809-1261

UNIEURO, Brasília, número 24, Julho a Dezembro de 2018, pp. 288-309.

[9] Didier Jr.,Fredie. Curso de direito processual civil: introdução ao direito processual civil, parte geral e processo de conhecimento. 17.ed.-Salvador:Jus Podivm, 2015. V.1. p.170

[10] Didier Jr.,Fredie. Curso de direito processual civil: introdução ao direito processual civil, parte geral e processo de conhecimento. 17.ed.-Salvador:Jus Podivm, 2015. V.1. p.170

[11] Donizetti, Elpidio. Curso didático de direito processual civil. 20.ed.rev.atual. e ampl: São Paulo:Atlas,2017.

[12] Donizetti, Elpidio. Curso didático de direito processual civil. 20.ed.rev.atual. e ampl: São Paulo:Atlas,2017. 